\title{
Four questions on curriculum development in contemporary South Africa
}

\author{
Ernst Wolff \\ Department of Philosophy, University of Pretoria, Tshwane, South Africa \\ Centre d'étude des mouvements sociaux, EHESS - CNRS, Paris, France \\ ernst.wolff@up.ac.za
}

This article explores current issues in South African philosophy curriculum design. Four questions are considered, each followed by a supplementary note. Firstly, the place of philosophy from other traditions, particularly Western philosophies, in South African curricula is considered (rather than the place of African philosophy in curricula). The related note reflects on whether different philosophical traditions in curricula should be treated separately or integrated. Secondly, ambiguity in some important authors' reception of plural traditions is identified and investigated to see what we can derive from their example for our philosophical practice. The related note looks at "decolonisation of the curriculum". Thirdly, I affirm the importance of relevance as a criterion for curriculum development, interrogating the meaning of this criterion for philosophy. The related note focuses on interpreting student feedback. Fourthly, the continued presence of "white" lecturers in South African philosophy departments is discussed against the background of the tension between the Mandela and Biko paradigms in contemporary society. The related note considers ideological resonances of our response to this issue in other parts of the world. Finally, the article's ideas are presented as an attempt to map argumentative options, clarify some of their merits and implications, and acknowledge their limits.

\section{Introduction}

One of the defining features of the contemporary political climate in South Africa is a tension between two competing paradigms for a just society. For the sake of simplicity, these paradigms can be identified using the names of two icons: Mandela and Biko. These paradigms overlap sufficiently for us to be cautious about a simple categorical opposition, but it is still legitimate to point out salient differences.

The Mandela paradigm is rooted in the conviction that the military impasse of the late 1980s was broken by a moral victory in line with the ANC's initial politics of non-violence. It sees the 1996 South African Constitution as the ultimate monument to that victory. It embraces inherited institutions, while acknowledging the need for some changes. It remains driven by a cultural logic of accommodation and reconciliation, and is non-racialist, considering measures such as black economic empowerment and affirmative action to be temporary corrective measures.

Adherents of the Biko paradigm ${ }^{1}$ regard the negotiated settlement of the 1990s as at best an intermediate step in the ongoing liberation of black people; ${ }^{2}$ but also often criticise that settlement as a mere continuation of historical violence — of apartheid and colonialism — by other means. Hence, Azania still needs to be liberated: politically, culturally, socially and economically. Constructs such as "post-apartheid" and "non-racialism" are seen as cornerstones of an ideology masking white privilege. All institutions inherited from the pre-1994 dispensations (from the legal system

1 Another descriptor could be chosen for the paradigm. I selected the name for the sake of convenience, to suggest a trend, rather than to identify the paradigm with one specific articulation thereof.

2 Throughout this article, I use the terms "black" and "white" to denote "races" as social constructions only. 
to language, from religion to academia) are suspect because they are seen as being structured by dissymmetries of racial privilege that cannot be corrected by the country's Constitution; pockets of black influence, power and wealth are merely part of the mechanisms by which white power and wealth distract attention from their unjust workings.

I will come back to this tension in Question 4. Whatever position we take on these questions, we should arguably welcome this tension in as far as it finds expression in increasing public awareness, questioning and political activity aimed at alleviating the social conditions which remain abhorrently unequal and unjust (both local conditions, and the position of our country vis-à-vis the rest of the world). Injustice indubitably often follows past lines of violence established by colonial powers and other mechanisms of racial prejudice, cultural arrogance and economic exploitation. Some of these forms of injustice (e.g. certain features of the economy) have patently increased since 1994, exacerbating rather than ameliorating inherited social inequalities. Finally, it is obvious that all social institutions are in some way subject to this injustice, often with debilitating effect.

In this context, there is a need for serious reflection on the discipline of philosophy and its teaching practices, as part of the national system of education - to be precise, not to start reflecting on what the current situation calls for, since some people have been working on these problems for some time, ${ }^{3}$ but to continue and intensify these reflections. These issues are too complex and too important to be dealt with carelessly. For this reason I express my dismay at the shoddy research, presumptuous slandering, Lévy-Bruhlesque mentality-talk, essentialising othering, arrogant and ignorant mockery, pulp ruminations, uncritical inversions (and therefore mimicry) of apartheid cultural logic, etc. often paraded as a critique of the university - sometimes even by people who air entirely legitimate concerns. However, I hasten to add that my dismay is not the fruit of a perceived arrivedness, as if I miraculously carried a memorandum against which to assess other points of view. The objective of my article is therefore not to open the eyes of the benighted, but to grapple philosophically with what, in my limited insight, remain unresolved issues. The most appropriate way of dealing with uncertainty seems to be frank, collegial debate and experimentation, to open up a future still unknown to all. However, I have been around long enough to realise that this statement of my basic position may already be suspected of being a conjuring trick to defend entrenched, unjust privilege...

The article is structured as a discussion of four questions, each followed by a supplementary note on a related matter. This does not amount to an exhaustive survey of the field, but reflects some of the main concerns raised at conferences, in the public media and in informal debate. Those who raise these concerns are my interlocutors in this article. ${ }^{4}$ The four questions are whether any philosophy from outside of Africa should be taught in South Africa, what the significance is of the ambiguity of philosophical practice in African philosophy, what relevance is, and whether white lecturers can be legitimate agents at South African universities.

\section{Question 1: Should any philosophy from outside of Africa be taught in South Africa?}

Throughout this article I will assume that African philosophy provides the default framework in compiling curricula. The aim of this assumption is to relieve African philosophy of having to justify itself, and is a strategy to break through the dilemma faced by African thought, captured in an ironic formulation by Fabien Eboussi Boulaga (2011, 219; my translation):

Either one has to philosophise or one does not have to philosophise. If one has to philosophise, one has to do it in the Western mode (the pleonasm is not redundant). And if one does not have to philosophise in the Western mode, in order to demonstrate that one does not have to philosophise in the Western mode, one still has to philosophise in the Western mode.

3 For example, Du Toit (1982), Shutte (1993), Malherbe (1996) - to cite only a few examples from the less expected side of the debate. These examples confirm the point, without denying the opposite historical tendency.

4 As evoked in this article when no specific author is indicated. 
The question I ask in the heading to this section is therefore by no means rhetorical. The question challenges the primacy and/or the often unquestioned presence of Western philosophy in our curricula. ${ }^{5}$ It also seems heuristically promising to invert the asymmetry of justification.

There was a time when various forms of Western philosophy were taught in all philosophy departments in South Africa and elsewhere on the continent and when people debated about the place that African philosophy may or should take in that framework. It is only at the expense of an anachronism that one can sneer at the fact that Western philosophy was the assumed point of reference five decades ago. One can get a clear impression of the uncertainty that surrounded the nature and status of African philosophy as a university discipline (which is the question here) from debates among African scholars in the early days - the earlier reconstructions of this history are particularly telling (Tshiamalenga 1979; Kinyongo 1982; Oruka 1987; Mudimbe 1988, ch. 5; Serequeberhan 1991). Today, the question of whether African philosophy should be part of a curriculum at our universities, has become an intellectual dinosaur. Lectures in African philosophy were introduced at the University of Zululand in the late $1970 \mathrm{~s}^{6}$ and at the University of Pretoria at the latest in $1990^{7}$, attesting to an emerging recognition that introducing African philosophy had become an inevitable development (which does not mean that the matter was thereby settled, as we all know; cf. Sesanti 2015, 348-349). Even considering the institutionalised practice of teaching Western philosophies as the unquestionable default mode now appears outdated.

Let us start, then, by taking for granted that philosophy curricula in South Africa should be composed of African philosophy. The history of scholarly work produced under the name of "African philosophy" in the last 70 years has resulted in a resounding affirmation of the need to practise philosophy on the African continent, and more specifically of practising modes of philosophising that (a) cannot directly be derived from Western forms of philosophising, and/or (b) are impregnated to such an extent by the burning questions faced by the people of this continent (in ways not shared by people elsewhere) that it should be considered constitutive of that practice. At the same time, the relation of African philosophy to Western philosophy has continuously been questioned, a debate which remains central to current discussions about philosophy curricula. If African philosophy has so successfully established itself as a tradition of philosophical practice alongside those of the West, the East and elsewhere, why bother with the historical and present forms of Western philosophy ${ }^{8}$ ?

My aim is not to arbitrate this question, but to demonstrate its viability and interest. Some fairly uncontroversial observations suffice:

- Many of the giants among African philosophers drew on Western philosophies, so thorough research of and teaching on their work requires familiarity with the debates in Western philosophy.

- The same argument holds for contemporary authors of African philosophy on the continent and in the diaspora. Assessing the contributions of authors in this field requires at least a basic knowledge of the traditions of Western philosophy. Furthermore, it is impossible to engage in contemporary postcolonial critique without thorough knowledge of the object of such critique.

- Teaching and research in Western philosophies remain widespread on the African continent. As long as this is the case, debates on Western forms of philosophising remain part of the intellectual life of this continent, and it may be worthwhile to prepare our students and ourselves to participate in it. This argument also applies if we consider possible collaboration with scholars in non-Western countries outside of Africa.

5 My entire approach is more progressive than that of Okeja (2012), in the sense that his article still advocates the rightful place of African philosophy in our curricula. Also note that his refutation of arguments for maintaining the dominance of Western philosophy in our curricula does not apply to my more modest arguments in favour of the possible continued value of Western philosophies in an African curriculum. However, his conclusions seem compatible with those I defend in the current section.

6 Fanie de Beer (personal communication, February 2016), on whose initiative this was done. Compare this to the first inclusion of African philosophy in university curricula in Nigeria in 1978 (Barry Hallen, Wits African Philosophy conference, 16 September 2015).

7 As confirmed by a study guide from this institution (Visagie n.d.). It has no publication date, but was obtained from an alumnus of the 1990 class. Responsibly reconstructing the motivations for introducing African philosophy in these departments is beyond the scope of this article.

8 Due to the contingencies of our history - and not because of principle - the questions regarding Western philosophy are of specific importance for curriculum development today. Some of the peculiarities of this issue will be dealt with in this article. For this reason, questions related to other than African philosophies will be demarcated to deal, most of the time, with Western philosophy. 
- Some of the concerns raised by African philosophers are shared by Western philosophers. These problems, the means of analysis and types of results are sufficiently compatible to consider some Western philosophers possible allies in these debates, making our familiarity with such literature desirable.

- Some of the sub-disciplines of African philosophy have not yet reached their full potential: philosophy of science and philosophy of technology are cases in point. Furthermore, it seems unnecessary for established areas of African philosophy to bypass insights which have already been worked out plausibly in Western philosophy and could be "domesticated" (cf. Wiredu 1998, 21-23).

- Many modes of Western philosophy developed in response to social and scientific developments of which former colonies will (at least for the foreseeable future) not be able to rid themselvesphysics, zoology, accounting, or again, state bureaucracy, international trade, etc. I know that African philosophers consider these issues-I doubt whether it is the best use of resources to do so in isolation.

This is not an exhaustive list of possible arguments, but they give us an idea of what a justification of Western philosophy in South African curricula may consist of. These arguments also suggest two general points:

- Taken together, they seem to be strong enough to caution us against rash calls for scrapping Western philosophy. This is not a trivial point: it relieves us from the arrogant conclusion that our colleagues elsewhere on the continent, who have enjoyed more years of independence but have maintained Western philosophy in their curricula, are merely willing instruments of self-assigned, continued self-colonisation (but the limits of validity of this point are captured by Okeja 2012).

- The arguments in favour of Western philosophy may well be weaker than generally assumed in our departments a decade or two ago. ${ }^{9}$ As far as I can judge they do not amount to repudiating the position of African philosophy as a default mode.

Reflection on this question also leads us to ponder the relation between African philosophy and other philosophical traditions (not only Western ones). Two cases in particular are of interest here. Firstly, we may equally well ask what the place of, say, Indian philosophy should be in our curricula. Many of the historical and political factors that made this question appear exotic a few decades ago ${ }^{10}$ have now eroded enough to expose the validity this question always had (cf. Haron 2014; Jagarnath 2014). In reflecting on the merits of developing, for instance, Eastern philosophies in our curricula, the specifics of the historical, cultural and political relations between South Africa and the regions of origin of these philosophies should be taken into consideration. Secondly, it seems prudent to hesitate over the relation between the Africana philosophy of the diaspora and continental African philosophy. One cannot deny the continued permeability of Africana philosophy to tendencies in Western intellectual life. Nor can one simply forget that Africana philosophy outside of the continent is shaped in response to the particular forms that social problems take in its places of origin. (Both these points are made especially bearing in mind Africana philosophy in the United States.) These are significant points, since a rejection of Western influence and an insistence on local problems are often cited to justify the institutionalisation of African philosophy and the rejection of Western philosophy at South African universities. One way to overcome this dilemma may be to point out essential similarities between the lived experience of continental Africans and diaspora Africans, such as experiences of blackness. However, this solution comes at a price: either we have to narrow down philosophy to a limited set of questions, or we have to open the door to other forms of shared experience, such as poverty, which also inform Western and other forms of philosophising, and in that way indirectly contribute to a justification of the inclusion of Western and other philosophies.

The reader may well ask to what degree the heuristic strategy of declaring African philosophy the default mode for curriculum design reflects a normative priority (or whether the priority implied by a "default status" needs to be maintained). I am not able to decide this question. However, two

9 Based on current trends, I predict that the gradual loss of status of Western philosophy will probably mean the disappearance of "Continental" philosophy from South African curricula in the next two decades.

10 I salute a notable exception, Versfeld's essays, collected in 1979. 
things seem clear: firstly, a plausible response is impossible without trying out both sides; secondly, this question cannot be settled without answering the three other questions that I discuss below. But before we get there, I would like to add a note on the coordination of African and other philosophies in our curricula.

\section{Note 1: On integration and separation in the curriculum}

If we conclude that elements of more than one tradition have to be maintained in our curricula, the next essential consideration is how to accommodate and coordinate them in one curriculum.

Two general types of coordination are possible. The "dedicated module" approach separates course material from different traditions into individual courses, each dedicated to material selected from a particular tradition. The "integrated module" approach juxtaposes material from different traditions in the same course according to the requirements of a particular theme. Each approach has advantages and disadvantages. The "dedicated module" approach seems to be the dominant paradigm on the continent. It allows enough space to present the material of each tradition on its own terms, for instance, by focusing on the historical development of themes within a tradition and in relation to the debates of a particular time or place. It has the drawback of failing to address overlap, dialogue and debate between traditions. Even worse, separate presentation of African philosophy may inadvertently create a dreadful quarantine or "Bantustan" effect, when separation is associated with isolation or second-rateness (this may happen even where African philosophy is the biggest component of the philosophy curriculum, but is a smallish part of a student's overall study programme). The main drawback of an "integrated module" approach consists in the relatively limited time it can afford to set aside to present the material of each particular tradition in the context from which it emerged. However, it succeeds better in establishing relations and debate between authors of different traditions. Furthermore, it seems entirely compatible with the spirit of the "integrated module" approach to present modules containing only African philosophy or only material from other philosophical traditions where the chosen course theme justifies such a restriction.

Arguably, these pros and cons suggest that alternating between the two approaches is the preferable solution. There is, however, still enough uncertainty regarding the relative merits of each approach, to warrant more experimentation with, ${ }^{11}$ review of, and debate about the alternatives.

All positions on the allocation of space to different traditions of philosophy in the curriculum depend on the way we deal with three more fundamental questions. I now turn to the second of these questions.

\section{Question 2: What is the significance of the ambiguity of philosophical practice in African philosophy?}

Allow me to introduce this point by ruminating on a simple fact: Fanon wrote in French, Biko wrote in English, an unfortunate circumstance that arose from violent historical events. Nevertheless, by writing in French and English, these authors by implication acknowledged that this element of their colonial heritage - the language of the colonial powers - has the potential to be more than an instrument of oppression: it can be turned against its source. It is possible to write in English against the British colonial legacy. This is what I mean by ambiguity: the origin of a cultural phenomenon does not necessarily determine or exhaust its potential.

This ambiguity is manifestly broader than just the question of the language chosen for expression. It equally involves the entire social-institutional constitution of philosophy in as far as it is a university discipline. Consider the class situation of teaching, recourse to prescribed material, external examination, fitting philosophy into a broader course (in the case of undergraduate studies), appointing lecturers with university training to teach, funding all such activities from state funds (at least at public universities), requiring 12 years of schooling of sufficient quality as a prerequisite for entry to university, etc. ${ }^{12}$ These are elements of the actual lifeworld and practice of philosophy,

11 During the past years I have tried several permutations of an "integrated module" and some "dedicated module" approaches and am happy to discuss these with colleagues.

12 On the institutionalisation of philosophy as symbol of power, see Eboussi Boulaga (1977, 87-97). For a historical and comparative view 
the teaching of which is our present concern. But even a cursory general knowledge regarding the divergent histories of philosophical traditions in the world indicates that these are not traits of philosophising as such. These are only the constitutive traits of the modern Western discipline of philosophy. In short, the university discipline in question is part of the Western cultural heritage. And this is true of the practice of education in philosophy, independent of any Western philosophy in the curricula.

There are two ways of dealing with this fact that do not take recourse to ambiguity.

Position (A). Some would conclude from my observation above that the discipline of philosophy is purely Western and can remain excellent only by remaining true to the traditions incorporated in its content and practices. There would then be no essential discontinuity between the philosophy practised in countries where these contingent traits of philosophy originated and where it is now practised. Western philosophy is perfectly exportable. ${ }^{13}$

Position (B). Others would conclude that the university discipline of philosophy is purely Western and therefore it cannot be salvaged from its embeddedness in a continuing history of cultural domination. There is then no continuity between Western philosophy inherited from the colonial past and the postcolonial philosophy that we have to promote here; the apparent continuities are thus obstacles to expanding African philosophy to its rightful place in society. Western philosophy is taboo. ${ }^{14}$

I reject both these extremes. Paying attention to the ambiguity of philosophical practice (in the sense described above) justifies my doing so, as I hope to show below.

Let us start by considering Position (B). Proponents of this position argue that Western philosophy is entirely a colonial (or neo-colonial) imposition. Teaching it implies loyalty to the world from which it originally came, at the expense of contemporary South African society - a loyalty which, if not expressed explicitly, may be found implicitly, for instance in "uncritical mimetic behaviour", a mindless imitating of imported academic gestures. I will not perform the artificial contortions of reason required to deny some truth in this assertion. Instead, I demonstrate the gravity of this claim. The examples I cite suffice to throw a shadow of doubt over Position (A). Then, in two steps, I attempt to demarcate the limits of this result in debate with Position (B). In all three steps, I cite anecdotal evidence, which can, of course, provide no more than prima facie support for my argument.

Some extreme cases demonstrate the kind of harm that can be done, as three well-known examples from three generations reveal. The most recent example is the infamous blog written by Louise Mabille in August 2013. ${ }^{15}$ Her reflections on Western feminism disastrously slid into a claim about black culture and the raping of babies. One generation earlier, G. J. C. van Wyk drew the attention of Robert Paul Wolff (1986), who, in his report on the state of philosophy in South Africa, recounted his discovery of Van Wyk's essay "Rawls, justice and apartheid". ${ }^{16}$ R. P. Wolff $(1986-87,97)$ castigates the article as "nothing less than a Rawlsian defence of apartheid", adding drily: "I think it is fair to say that this is not quite what Rawls had in mind when he elaborated his theory of justice". Yet another generation earlier, A. H. Murray testified catastrophically for the State in the Treason trial of 1957-1961. Acting as expert witness, he claimed to be able to identify communist tenets in any text. He subsequently identified such tenets in a number of anonymous texts submitted by the defence-including some texts predating Marx, non-Marxist texts and one by Murray himself (Troup 1975, 58-60; Barnes 2013).

on the modern institutional forms of African universities, see Mamdani (2016). Acknowledging this heritage does not amount to elevating it to an inescapable fate. My article is concerned with the conditions for mastering this heritage.

13 It is not only scholars of Western origin who may be tempted by this stance. In his early work, Hountondji ([1976] 1983) was close to this position.

14 This implies that insights from African philosophy cannot, without essential loss, be introduced into Western philosophy.

15 The blog has subsequently been withdrawn and deleted.

16 I have not been able to get a copy of Van Wyk's article and cannot confirm that it was ever published. 
There may be attenuating circumstances unknown to me or ways to contextualise each of these anecdotes, but that is not the point. These three anecdotes evoke the least glorious side of Western philosophy in South Africa. In all fairness, these examples would probably be disowned by the very traditions they aspired to represent; nevertheless, they adequately illustrate the fact that a background in Western philosophy is no safeguard against ideological calamity. If this is true for these notorious cases, it may be true to a lesser extent in other cases. The question is whether such ideological drifting inevitably accompanies Western philosophy in our country (and of which the mimicry of Western practices may be a symptom). Raising this question is the valid part of Position (B).

If these three episodes encapsulated the story of Western philosophy in South Africa, there would be nothing to redeem it. However, one can easily find quite different examples. I cite three, again they are drawn from three different generations and authors working in three different sub-traditions. In his book Oor gode en afgode [On gods and idols], Martin Versfeld deployed more or less neo-Thomist means to produce a radical critique of war, exploitation and global imperialism. He turns his critique against racism:

The whites accelerated their self-exploitation by the exploitation of other races. Through the inventiveness in the terrain of transportation and explosives they came in a position to use non-whites as means to their [the whites'] own ends (Versfeld [1948] 2010, 169).

Elsewhere he lamented the fact that South Africa imitated German race politics (cf. Wolff 2010, 15). Finally, he rejected Christian nationalism as a contradiction in terms (Versfeld [1948] 2010, 137-138). That was in 1948.

A generation later, Rick Turner (who concluded his formal education with a thesis on Sartre) argued in the essay "The relevance of contemporary radical thought" that race

is in two senses very much a "secondary reality". Firstly there is no factual basis for beliefs about racial inferiority, or about the inherent unpleasantness of members of other "races". White prejudice against blacks is based on ignorance, whereas black hostility to whites is based on the hard facts of exploitation. Secondly, it is probable that, in South Africa at least, race prejudice plays an important role in justifying to the whites their right to treat the blacks in the way they do. That is, it is in some ways a rationalisation of exploitation: in addition it is reinforced by the effects which exploitation has on the blacks. Black hostility to whites is based on real grievances. White hostility to black [sic] is based on the realisation that the blacks threaten white privilege. Conflict will not end until the grievances and the privileges end. But once these have ended, there is no basis in race difference for further conflict. That is, there is no reason why whites should expect to be discriminated against in a democratic South Africa because of their whiteness (Turner 1971, 79).

The fact that his essay is steered by a Marxist, Marcusian analysis of the contemporary sociopolitical problems of South Africa does not blind him to the importance of Black Consciousness, which he acknowledges in the same essay.

Another decade later, Johan Snyman (1985) submitted the first doctorate on the Frankfurt School Critical Theory in South Africa. In his preface, he reflects on the meaning of such a study on Adorno amidst the reality that it had become "more than apparent that the socio-political structures of South Africa had become unbearably useless" (Snyman 1985, ix). If Adorno's philosophy responds to the horrors of the Second World War in Europe, what does this have to do with South Africa in the 1980s? Snyman explains by pointing out the common denominator, namely of a society under identity-control:

The mainstream of governmental politics and Afrikaner thought was blind to the critical self-reflection [like that of Adorno] of the European experience. That South Africa is burning today and lives through the dreadful expressions of hate for a political system, can no longer be placed on the account of agitators "from the outside". The system is not that innocent. It is all, at least partially, also the consequence of a philosophy of identity that was 
as particular as the one analysed by Adorno, and which has its roots in exactly the same soil as the European crisis that Adorno deciphers, namely the dialectics of the Enlightenment... In the name of protecting identity, the identities of communities were destroyed, for example by "social engineering" dislocations. In numerous laws the interests of the individual had to yield to a particular group's interest. This is South Africa's own dialectic of the Enlightenment, which spreads the stench of Auschwitz through the world without the gas chambers or crematorium of Auschwitz. This is what still has to be understood in South Africa, especially by the Afrikaner (Snyman 1985, xi-xii) ${ }^{17}$

A few months later P. W. Botha announced the state of emergency.

A lot would have to be said to present the exact profile of these three quite different examples in the context of their work of origin and to situate them in respect of the ambient political context. However, it is fair to claim that despite being rooted in Western traditions of thought, there is more than mere uncritical mimetic behaviour here and it would be unfair to declare that it was foreign to the place for which it was written. This is arguably as strong as the counter-evidence against a blanket accusation of Western philosophy as instrument of (neo-)colonialism gets. Obviously three anecdotes do not suffice to salvage so many decades of problematic practice. But they do testify to the possibility of putting the ambiguity of the Western heritage to good use.

But how strong is this point really? Someone may well concede that some moments of Western philosophy are less catastrophic than others, but still consider this only as a relative good of a practice that should, as a whole, be condemned as an illegitimate imposition. The broad name for evoking the insufficiency of even its best moments could be "liberalism". None of the three authors I cite above would accept this label, but they would fall under it in the broad sense used by Biko ([1978] 2004, 51, 89-90). Arguably all (political) philosophy practised by white authors during the years of apartheid who were explicitly against apartheid policies would be categorised as "liberal" by Biko. To make the point of the ambiguity of this heritage I would therefore have to go along with the sceptic's critique of "liberalism" and see if this ambiguity of tradition is testified to in the work of African thinkers. I again use three somewhat anecdotal examples, from three different generations.

In his foreword to the collected writings of Anton Muziwakhe Lembede, A. P. Mda explains that Lembede "rounded off his education by earning an M. A. in Philosophy" (Mda 1996, xv). Mda refers here to the studies that culminated in Lembede's dissertation entitled The conception of God as expounded by or as it emerges from the writings of great philosophers from Descartes to the present day. The full dissertation is not included in the collected writings, but according to the publication note accompanying an extract from the dissertation, these "great philosophers" discussed by Lembede include some ancient Greek philosophers, Descartes, Leibniz, Spinoza, Hume, Kant, Hegel, and William James (Lembede 1996, 105). Mda reminisces:

While he was studying and preparing for his thesis for his M. A. degree, we were staying together in Orlando East. We had extensive discussions because he was studying the philosophers from Descartes to the present day. Now that was very fortunate for me because he used to invite me to take part in discussing some of the issues raised by the philosophers. Very often we took opposite positions...And after explaining to me so and so stood for this and that, he would make a reference to some book. He read to me, and I would read myself. Then we would discuss issues that he wanted to go deeper into. He invited me to take a certain line, an opposite line, so he could give me a chance to go deeper (Mda 1996, xv).

My point here is not focused on the dissertation text itself, for nothing in it distinguishes Lembede from a Western philosopher. The point is rather Mda's account of the reception of those Western philosophers by himself and this articulate Africanist (also see Edgar and ka Msumza 1996, $21 \mathrm{ff}$.

17 I had the great fortune of being Snyman's student in the mid 1990s. In his lectures on modernity and the Enlightenment he taught his students that every attempt at assessing these big sociocultural developments has to engage with Adorno's ([1966] 1973, 357-358) arguments for claiming that Auschwitz exposed the fact that Western culture is garbage, built on shit. Consequently, I struggle to understand what people are speaking about when they reduce Western philosophy to a long, uninterrupted ode of self-congratulation. 
especially): it is not an account of two victims, but of two eager students engaging with stimulating material on their own terms.

A generation later, Steve Biko, in "Fear - an important determinant in South African politics", argued that white South Africans were collectively guilty of the miserable situation of blacks - not on the basis of any existing law, but on the basis of "metaphysical guilt", that is, the guilt of those who could have prevented crimes, but did not. Biko draws this concept from Karl Jaspers, whom he cites (Biko [1978] 2004, 78). ${ }^{18}$ Elsewhere, in "Black souls in white skins", Biko again draws on Jaspers' idea of metaphysical guilt (this time, however, without naming him) and the point is similar: since white people collectively tolerate the injustice inflicted on black people, they are collectively guilty of this metaphysical guilt. This reference to Jaspers is all the more significant if one notes that Biko, on the same page, rails against (liberals") "ill-defined philosophical concepts that are both irrelevant to the black man and merely a red herring across the track", adding that "[w] hite liberals must leave blacks to take care of their own business while they concern themselves with the real evil in our society-white racism" (Biko [1978] 2004, 23). The conclusion is clear: Jaspers' philosophical concept is not ill-defined, is relevant to black people, and is no red herring; taking recourse to Jaspers' notion is a legitimate way for Biko (and Fanon ${ }^{19}$ and others) to concern himself with the real evil in society.

At the beginning of the new millennium, Mabogo More submitted a thesis in which he denounces the relative absence of philosophising on race as in itself a manifestation of racism, and sets out to make his contribution in the spirit of Africana existentialism, following with Gordon the lines connecting Fanon, Biko and Manganyi. For current purposes, it is the way he goes about achieving this that is of interest. He tackles this task in his Sartre and the problem of racism by identifying his central objective as investigating "how Jean-Paul Sartre's philosophy can be useful in understanding the problem of racism" (More 2005, 1). More's study is a rich exploration of diverse components of the problem of racism. He summarises the unifying structure as follows:

This study will, therefore, map out the theoretical articulation of the problem of racism in Sartre's major philosophical texts and his application of this framework to concrete existential situations. Put differently, the goal is to reconstruct Sartre's ontology to the concrete ontic issue of racism. We shall, in doing this, advance the thesis that Sartre, in his popular political, literary and social writings, employs a theory of antiracism which attains its reflective grounding in his philosophical works (More 2005, 17).

Furthermore, in Chapter 6 of his study, he devotes much energy to trace the reception of Sartre in Fanon, Biko and Manganyi. In short, More's project says as much about the potential of (some parts of) Western philosophy to be of real importance in the South African context as it does about Western philosophy as a violent imposition.

As in my previous series of examples, precise historical and biographical information may be brought to bear on these anecdotes to contextualise, complexify and/or relativise their significance. However, I do not anticipate that such work would deny that aspects of Western philosophy have long been recognised by black South Africans to be stimulating, useful and important, and could be mobilised for entirely legitimate causes, despite their Western origin. And this is the point I am steering towards: not making an impossible case for the innocence of Western traditions of thought ${ }^{20}$ but the fact that those traditions are recognised by significant African intellectuals as ambiguous and that making use of the positive side of that ambiguity is not an accidental part of the very practice of their African thought. ${ }^{21}$

18 The text in question is Jaspers's (1946) reflection on the "question of German guilt".

19 I do not know if Biko ever read Jaspers-it is possible that he learned about Jaspers from Fanon ([1952] 1986, 89, n. 9) - but I do not believe that this changes my point.

20 My three examples are not intended to be a plea for the inevitability and perhaps superiority of Western philosophy. I explicitly reject Position (A). Recognising the ambiguity of the material in question is quite different from a colonialist "assumption that theory is produced in the West and the aim of the academy outside the West must be to apply that theory" (Mamdani 2016, 81).

21 My point in the discussion of ambiguity is neither to declare illegitimate the quest for pure forms, e.g. of African philosophy, as cultural strategy (I have expressed my support for it in writing, see Wolff [2013]), nor to advocate mixing of traditions as the only legitimate and good philosophical practice in South Africa. 
If Western philosophy has an ambiguous history and potential, and if that ambiguity is echoed by the positive appropriations of parts of it by African philosophers who are convincing critics of Western thought, then the task ahead-supposing we take African philosophy as our default setting - is to determine what the benefits would be of still including Western philosophy in our curriculum (a part of this case has been made by the positive half of the ambiguity) and what could be done to strengthen the positive contributions thereof (against the negative possibilities). This entire argument could obviously be developed from the side of African philosophy too, and it seems plausible to expect that it would show up similar forms of ambiguity.

\section{Note 2: On "decolonisation"}

One of the key concepts by which people try to capture the task of improving institutions in the former colonies is "decolonisation". This is a major issue-for some even the heading under which this entire question should be dealt with. Here I can focus only on a few ideas, aimed at enriching the question of ambiguity.

Consider first, the most elementary meaning of the term "decolonisation". When imperial powers subjected other regions of the world to their power, they colonised them. To undo this colonisation, these regions had to be de-colonised, that is, do away with the imposed power. A decolonised state is a state that has got rid of colonial rule. Or is it? Post-independence life abounds in experiences of continued influence coming from the former colonising powers, even when those powers are not actively promoting that influence. Thus, it is not only territories and populations that can be colonised, but all aspects of life, up to and including the mind.

In a sense, it is easier to undo the imposition of foreign rule than to do away with the other elements of colonial heritage. The state of the university and curricula is an eloquent example of this. How can one decolonise the university without keeping in mind that the university as we know it is itself part of the colonial heritage? Strictly speaking, "decolonising" the university requires doing away with universities. Likewise, to decolonise a curriculum does then not mean to replace Western philosophical content with African philosophical content, because the entire social-institutional construction of curricula (cf. Question 2 above) is part of the colonial heritage. Decolonising curricula would mean abolishing curricula and re-institutionalising non-university practices of education in their place. Thus far, I have not heard anybody making a case for decolonising universities and curricula in this sense even if this is precisely what a radical critique of (neo-)colonisation ultimately amounts to.

We seem to be stuck with the fact that decolonisation cannot be exhaustively practised, or that even the fiercest critics of the colonial heritage do not want to take the notion of decolonisation to its logical conclusion. This is a nasty fact about history: it cannot be undone completely. It therefore appears that calling for institutional change on the basis of an unqualified rejection of the entire colonial heritage must be hypocritical.

I maintain that the only intellectually honest way to continue with the very important task of critiquing the colonial heritage, is to understand "de-" of decolonisation in terms of the ambiguity (as I have explained it above). Correspondingly, de-colonisation should entail the abolition of parts of the colonial heritage, but this has to be underpinned by an assessment of the ambiguous potential of that heritage. The "de-" of decolonisation would further also refer to liberating the colonial heritage as far as possible of harmful effects and deploying the remaining heritage in the service of that emancipatory project. Biko decolonised philosophy in the way he deployed Jaspers; Snyman

The difference between me and disciples of Ngũgĩ wa Thiong'o (1986) lies in the fact that they elevate the purity of the own—both against the purity of the oppressive other (the empire) and against forms of "bastardisation" of ambient culture - to the exclusive legitimate form of postcolonial cultural strategy. I argue that recognising mixing accommodates everybody's free choice of cultural strategy, including quests for purity; by contrast, pursuing purity as the exclusive and ultimate value cannot tolerate such mixture. Therefore, the following remark by Fanon does not apply to me: "Some have been surprised by the passion invested by the colonised intellectuals [like Ngũgĩ wa Thiong'o] in their defence of a national culture. But those who consider this passion exaggerated are strangely apt to forget that their own psyche, their ego, are conveniently safeguarded by a French or German culture which has proved itself and which nobody disputes" (Fanon 1965, 209; translation modified). Besides, I reject with equal vigour similar exclusive quests for purity in Western culture and philosophy.

Regarding the diversity of cultural strategies Olúfémi Taiwò (2010) is much more perspicacious (see especially his introduction). 
decolonised philosophy in the way he deployed Adorno. Decolonisation then may entail partial consent to or appropriation of the heritage against which it is directed. ${ }^{22}$

But such a practice of decolonisation needs to be informed by normative reflection. We now turn to one aspect of such reflection.

\section{Question 3: What is relevance?}

One of the criteria that people apply in assessing the quality, as well as the legitimacy, of curricula is relevance. ${ }^{23}$ In this, philosophy is not alone, and the situation in South Africa is not unique (Mamdani 2016). Two dimensions of the current debate about relevance are (a) the frequent identification of relevance with Africanisation, and (b) the frequent equation of relevance with immediate applicability. While I affirm relevance as a criterion for curricula, it is not always that clear what the term means.

(a) In current debates one often hears that Africanisation, understood as the replacement of Western philosophical course content with African philosophical material, is called for to improve and guarantee the relevance of courses. This raises the question of whether African philosophy in a course programme is a sufficient condition to qualify the course content as relevant. Since it is evidently possible to make of Western philosophy a practice-foreign, sterile intellectual exercise (in Africa as much as in Western countries), would it not be fair to assume that one could do the same with African philosophy? ${ }^{24}$ It is plausible to maintain that no form of philosophy is "relevant" by definition. What then qualifies a curriculum as relevant?

I would like to suggest that the question of relevance is so closely related to the one on ambiguity that I can safely recycle the examples from Question 2 in this context. Using the question of pressing political questions as reference, I have in each case implicitly applied the requirement of relevance: the six last authors cited did not only write things that were true or insightful, but things that were relevant to their context. ${ }^{25}$ Only because I anticipated that any reasonable reader would grant the legitimate relevance of the work of these authors could I make the case that the colonial philosophical heritage and recent Western importations were ambiguous. Biko could take advantage of Jaspers because he could show how Jaspers was relevant to his argument on extra-judicial guilt; similarly Snyman's work on Adorno was relevant to analysing the identity violence of the apartheid system. This suggests a number of implications:

- It follows that it is judicious not to consider Africanisation (defined as purifying a curriculum from Western influence) as a criterion for relevance. Instead, we should first determine what Africanisation is in the light of the criterion of relevance: Africanisation should not be understood as mechanically swopping one body of work for another, but as a demanding intellectual work of (re-)deploying whatever cultural goods we have access to, to the advantage of solving the pressing questions of this continent, one of which is decolonisation. ${ }^{26}$ Most profoundly we want to know if the material presents a plausible likelihood of clarifying a non-trivial part of our living reality. By the way, this means that we should not reduce relevance to sociopolitical issues, as if Africans have to go on an intellectual diet prohibiting them from philosophising about technology, animal ethics, aesthetics, belief, scientific models, etc.

- Africanisation is then not something like a switch that is either turned on or off, ${ }^{27}$ but rather a process of continuous confrontation of curriculum design with the questions relevant to people's lifeworld. For this reason, Africanisation does not stand for the implementation of a

22 The decolonisation of philosophy evidently goes much further than that; see for example, Wiredu (1998).

23 Many other considerations were tabled in the Nzimande report. For a critical discussion thereof, see Wolff (2013, part 1).

24 Consider, in support of this claim, Masolo's (1986, 176-180) reflections on the relation between philosophy and social reality.

25 The example of Lembede is somewhat different. A difficult question that arises here is on the relation between true or legitimate arguments and their relevance. Surely one would be able to grant the relevance of an argument (or at least of the intention thereof) even if one does not share the author's view.

26 Merely stating "lecturer X prescribed readings from Western philosophy" does constitute a sufficient argument to qualify what happens in that class as un-African or irrelevant. Likewise, noting that "lecturer X prescribed readings from African philosophy" is insufficient to qualify the course as relevant. Both statements on their own, remain strictly under-determined.

27 For instance by doing or not doing African philosophy (over against Matolino 2015, 408-409). Matolino's argument implies that it is impossible for a devout Hindu or Communist to be a real South African and that philosophy is incapable of immanent critique. More nuanced is More (2006). 
specific content, but for a continuous quest for relevance, a quest of which the outcome is not known in advance. ${ }^{28}$

- In this sense, all African philosophy included in our curricula needs to be Africanised too. ${ }^{29}$

(b) Everything I have said above testifies to the fact that I am in favour of relevance as a criterion for the legitimacy and quality of curricula. I tie the first question on relevance to the second: applicability. But this makes the issue much more complex. We frequently hear relevance equated to immediate, even practical, applicability, but clearly university education is not necessarily designed for such immediate applicability. Immediate, practical application is not even a measure for teaching in engineering. The wager of much of university education is that the world needs, next to so many other valid and important forms of intelligence, also those forms which, through sustained attention to the underlying questions of fields of study, prepare the students for the longer-term work of problem-solving in diverse uncertain situations. This is true for philosophy too.

It may even be more true for philosophy ${ }^{30}$ than for other disciplines. Is philosophy not precisely an intellectual practice of withdrawal from immediate urgency, that is, from direct applicability? Or to be more precise: even when it seeks to help people understand their world, philosophy exists by virtue of taking detours in preparation for its views. These detours may be very long. The relevance of philosophy cannot be measured by the way it comments on the newest news headlines alone (cf. also Masolo 1986, 178). For this kind of immediate applicability, other forms of human intelligence exist. The need for long detours seems to me to characterise all traditions of philosophy. ${ }^{31}$

However, it needs to be acknowledged that we embark on long detours at the risk of getting lost. It is true that the praiseworthy virtue of free and radical thinking, which characterises the best of philosophy can also be the lure which leads able philosophers astray into lands of reflection from whence we cannot recall them to our world with its joys and problems. I cannot see that African, Western or any other philosophers are immune to the risk of straying into irrelevance. ${ }^{32}$

\section{Note 3: On students' reception}

Quite regularly in debates about the curriculum, it is mentioned that students - here black studentsin general have an experience of estrangement due to the course content. What is taught at university does not fit into what they learn at home, it is often said. But in my view this is not necessarily a problem. I remember very well, for instance, how some of my own classmates experienced the confrontation of the racism they had picked up at home with anti-racism at varsity — with salutary effect. If staunchly creationist students of biology are shocked by the theory of evolution, I sympathise, but do not see this as sufficient reason to change the biology curriculum. There are a number of reasons why, in philosophy too, students may have to deal with a tension between what they have learned at home and what they study in class. ${ }^{33}$ These remarks are not intended to dismiss the reported experiences of some students. Such reports may be a way in which cultural bias in the curriculum is registered. My point is that there is no direct correlation between students' disorientation by study material and the illegitimacy of teaching such material.

A second, related, claim that is quite often made is that black students experience alienation and frustration when confronted with Western philosophy. Intuitively, I find this claim plausible. However, there is a problem. Over the last decade I have regularly requested student feedback by means of my home institution's pro forma lecturer evaluation instrument. This questionnaire gives students an opportunity to anonymously score a series of aspects of the lecturer's work (using

28 This point is very close to that offered by Serequeberhan (1994, particularly in Chapter 4). It also shares the spirit of Taiwò (2010).

29 Macamo (2009) points in a similar direction. Obviously I reject the idea that philosophical material could be considered relevant to students and society on the sole basis that the authors are celebrated Western academics.

30 The question of "applied" philosophies would have to be dealt with elsewhere.

31 The detours I have in mind are the spaces one is able to allow oneself to enter into preparatory reflection before returning to practise anew. This is a different issue from that addressed by Matolino (2015, 406-408) regarding the degree of abstraction and concreteness involved in thinking. It is very possible that thinking aimed at dealing with concrete or local detail requires as long a detour or suspension of practice as abstraction does (cf. Eboussi Boulaga 1977, 96-97).

32 One can share Ikpe's (2010) critique of narrow utility maximisation and the corporatisation of the university, without sacrificing the demand for relevance.

33 On alienation as part of postcolonial existence, see Irele (1992, 206-207). However, I suspend judgement on the "praise" he reserves for alienation. 
a Likert-type scale) and to comment freely (qualitative feedback) on the entire experience of a course. Neither the qualitative, nor the quantitative part of the evaluation has ever indicated any disgruntlement with my course content (even when modules contained only Western philosophy). These questionnaires represent the opinion of hundreds of black students over the years. ${ }^{34}$ These data directly contradict my intuitive acceptance of the claim. I conclude that in-depth social scientific research on this subject is required to clarify the matter.

\section{Question 4: Can white lecturers be legitimate agents at South African universities?}

At this point I would like to return to the opening lines of the article. One could recapitulate that the Mandela paradigm and the Biko paradigm represent a fundamental dispute of the meaning of the 1994 settlement. Implicitly, this dispute played a role in the argumentative alternatives unpacked in response to the first three questions. One particular implication of this dispute, for philosophy, to which I now turn, is that the legitimacy, with which the majority of our current lecturers may teach and even participate in these debates, is itself at stake.

The Mandela paradigm finds its classical expression in the Freedom Charter: "We, the People of South Africa, declare for all our country and the world to know: that South Africa belongs to all who live in it, black and white..." (African National Congress 1955). This basic view of legitimate citizenship has been institutionalised in the Constitution. As long as this paradigm remains in force, and is generally consented to, there could be no objection in principle to "whites" teaching at the university. Only the number of white lecturers could pose a problem.

Opposition to this inclusive view has today regained public visibility. Often, those who question the Mandela paradigm do so with reference to Fanon. Some consider the post-1994 dispensation to be nothing but a masked continuation of apartheid and may appeal to Fanon: "The problem is clear-cut: the foreigners must leave. Let us build a common front against the oppressor and let us reinforce it with armed struggle" (Fanon 1965, 83). Others are a bit more lenient and are willing to recognise some difference between South Africa prior to 1994 and since 1994, in that they may at least concede that the former enemies may become "negros or Arabs" (Fanon [1961] 2002, 139; translation corrected), in other words, fight on the right side. But this would still mean that Biko gives the appropriate exegesis of this principle for our current context:

Therefore we wish explicitly to state that this country belongs to black people and to them alone. Whites [the "clique of foreigners", [1978] 2004, 27] who live in our-who live in this country [have to live here] on terms laid down by blacks and on condition that they respect the black people (Biko [1978] 2004, 121). ${ }^{35}$

The cultural-political implications of this point of view is made explicit by Serequeberhan, when he states: "The settler cannot indigenize and remain a settler. His existence is innately parasitic. He is dependent on the mother country for his spiritual and historic legitimacy as a colonizer, and on the colony for his socio-economic existence and pre-eminence" (Serequeberhan 1994, 83). In short, with regard to white lecturers (and arguably other lecturers who may be considered insufficiently African), this stance advances the illegitimacy of their presence on their own terms and/or the requirement of assimilation to real African cultural standards (however this is defined).

The thrust of my article does not commit me to the task of declaring the winner between these two paradigms and I frankly admit that at this stage I do not see how to arbitrate this matter conclusively. Nevertheless, it is important to note that it is impossible to write such an article without at the same time implicitly situating oneself in this debate. That I wrote from a position more congenial to the Mandela paradigm cannot be denied. In fact, to suggest some ways to deal with curriculum issues (as in Questions 1 to 3 above), I needed, at least for the sake of the argument, to keep the possibility open that the second paradigm is flawed. At the same time the Biko paradigm has the merit of clearly foregrounding two most fundamental questions underlying all reflection on curriculum development in our time, namely the question of what qualifies someone as legitimate to speak, and

34 Informal communication with students rather indicates that teaching in Western philosophy is experienced by many black students as a very valuable contribution to their reflective engagement with the world.

35 To do justice to Biko's point requires more discussion. Similarly, Lembede $(1996,91)$. 
the question of the dominant narrative of our contemporary history in Azania. An approach to the curriculum that has no response to these questions is built on jelly.

\section{Note 4: On unfortunate resonances}

In this short note I would merely like to point out one consequence of following the Biko paradigm (without thereby giving sufficient reason to discard it entirely). The passionate spokespeople of this paradigm are often outspoken in their antipathy to the West. The flipside of this quest for self-sufficiency is that they do not sing for Western applause. However, often this posture is informed by a homogenous picture of the West. Seldom, if ever, have I heard any reflection on the significance of newcomers (Africans and others) to Western countries. A disparaging attitude towards the culture and political power displayed by Western states makes sense in this context, but it makes less sense to give no thought to the position of exiles, migrant workers, refugees or generations-old cultural minorities in those states. With the fate of such people in mind, the question of resonance is a factor to bear in mind for the sake of one's self-understanding, and should not be neglected.

It is true that nowadays the general population in the West seems to be becoming politically more conservative compared to a decade or two ago (see Boltanski and Esquerre 2014; Brumlik 2016), but these societies group together a plurality of political views that are not adequately captured by the general tendency. It would be extremely ironic if the discourse of the Biko paradigm would find its most audible resonance not in the parties and associations that struggle to improve the fate of minorities, but in the discourse of the extreme right-wing groups in the West. I am thinking here of resonances with the extreme right's essentialism and stereotyping of others, nativism, scape-goat thinking, humiliation of other forms of knowledge and the like. The recourse to mono-causalracial - explanations of all social phenomena does not help to counter such resonances. ${ }^{36}$ I do not wish to suggest that the Biko paradigm is a copy of a Western extreme right-wing ideology, but want to caution that we would overlook something important if we did not engage seriously with these unfortunate resonances. ${ }^{37}$

\section{Conclusion}

The ideas and arguments above contribute to a mapping of the argumentative options in the debates related to philosophy curricula in South Africa today. I have attempted to clarify some of their respective merits and implications, and to argue at some places for their limits.

This does not add up to a blueprint. Nor does it suffice to establish definitive practical directives for philosophy curriculum development. Rather, based on my current state of insight, the arguments above are intended to assist in continuous reflection on the philosophical questions underlying curriculum design. I would advocate a context-sensitive approach, but we urgently need to reinvigorate our planning with reflection on the underlying issues or stakes, as we work on the planning itself. The article reflects my conviction that curriculum design is still subject to great uncertainties. We have still to discover much of what "relevance" and "decolonisation" and "Africanisation" mean. I advocate an approach of learning through experimentation, review and debate.

My objective was to deal, albeit briefly, with some of the most important questions, but I have left out one other radical question: philosophy curriculum planning will remain disoriented in the absence of an understanding of what philosophy is and what it is able to do-socially, scientifically, politically, and personally.

\section{References}

Alexander, N. 1991. "Black Consciousness: A reactionary tendency?” In: Bounds of possibility: The legacy of Steve Biko and Black Consciousness, edited by N. B. Pityana, M. Ramphele, M. Mpumlwana, and L. Wilson, 238-252. Cape Town: David Philip. Adorno, T. (1966) 1973. Negative dialectics, Trans. E. B. Ashton. New York: Seabury.

36 To give but one example of the derailing effect that mono-causal explanations can have, see Ramphele (1991).

37 My point is not foreign to the spirit of questioning, advanced with greater affirmation by Neville Alexander (1991). 
African National Congress. 1955. The Freedom Charter. www.anc.org.za/show.php?id=72.

Barnes, T. 2013. "The curious case of Prof. A. H. Murray in South African trials, 1956-76." Unpublished paper presented at the "Rivonia Trial 50 Years On" conference, University of Pretoria, 18-20 June 2013.

Biko, S. B. (1978) 2004. I write what I like: A selection of his writings. Johannesburg: Picador Africa.

Boltanski, L., and A. Esquerre. 2014. Vers l'extrême. Extension des domaines de la droite. Paris: Editions Dehors.

Brumlik, M. 2016. "Das alte Denken der neuen Rechten. Mit Heidegger und Evola gegen die offene Gesellschaft." Blätter für Deutsche und Internationale Politik 3: 81-92.

Du Toit, A. 1982. "Philosophy in a changing pluralist society." South African Journal of Philosophy 1 (4): 154-61.

Eboussi Boulaga, F. 1977. La crise du Muntu. Authenticité africaine et philosophie. Paris: Présence Africaine.

Eboussi Boulaga, F. 2011. L'affaire de la philosophie africaine. Au-delà des querelles. Paris: Editions Terroirs \& Karthala.

Edgar, R. and L. ka Msumza. 1996. "Introduction.” In: Freedom in our lifetime. The collected writings of Anton Muziwakhe Lembede, 1-44. Athens: Ohio University Press.

Fanon, F. (1952) 1986. Black skin, white masks. London: Pluto.

Fanon, F. (1961) 2002. Les damnés de la terre. Paris: La Découverte.

Fanon, F. 1965. The wretched of the earth. London: Penguin.

Haron, M. 2014. "Islam, intellectuals and the South African Question." In: Intellectual traditions in South Africa. Ideas, individuals and institutions, edited by P. Vale, L. Hamilton, and E. H. Prinsloo, 313-332. Pietermaritzburg: UKZN Press.

Hountondji, P. (1976) 1983. African philosophy: myth and reality. Bloomington: Indiana University Press.

Ikpe, I. B. 2010. "Beyond relevance: In praise of useless knowledge." South African Journal of Higher Education 24 (4): 525-537.

Irele, A. 1992. "In praise of alienation." In: The surreptitious speech. Presence Africaine and the politics of otherness, 1947-1987, edited by V. Y. Mudimbe, 201-224. Chicago: University of Chicago Press.

Jagarnath, V. 2014. "The Hindu intellectual tradition in South Africa: The importation and adaptation of Hindu universalism." In: Intellectual traditions in South Africa. Ideas, individuals and institutions, edited by P. Vale, L. Hamilton, and E. H. Prinsloo, E.H., 268-290. Pietermaritzburg: UKZN Press.

Jaspers, K. 1946. Die Schuldfrage. Heidelberg: Lambert Schneider.

Kinyongo, J. 1982. "La philosophie africaine et son histoire." Les Études philosophiques (Philosophies Africaines) 4: 407-418.

Lembede, A. M. 1996. Freedom in our lifetime. The collected writings of Anton Muziwakhe Lembede. Athens: Ohio University Press.

Macamo, E. 2009. "Africa and Humanism." In: Humanism in intercultural perspective. Experiences and expectations, edited by J. Rüsen and H. Laass, 65-78. Bielefeld: Transcript. doi:10.14361/9783839413449-006.

Malherbe, J. G., ed. 1996. Decolonizing the mind. Proceedings of the second colloquium on African Philosophy. Pretoria: UNISA.

Mamdani, M. 2016. "Between the public intellectual and the scholar: Decolonization and some post-independence initiatives in African higher education." Inter-Asia Cultural Studies 17 (1): 68-83. doi:10.1080/14649373.2016.1140260.

Masolo, D. A. 1986. "Kwame Nkrumah: Socialism for liberation." Praxis international 2: $175-189$.

Matolino, B. 2015. "The place of South African philosophy in the future of South African philosophy.” Social Dynamics 41 (3): 399-414. doi:10.1080/02533952.2015.1092311. 
Mda, A. P. 1996. "Foreword." In: Freedom in our lifetime. The collected writings of Anton Muziwakhe Lembede, xv-xvii. Athens: Ohio University Press. doi:10.1093/ndt/11.supp5.1.

Mudimbe, V. Y. 1988. The invention of Africa. Gnosis, philosophy and the order or knowledge. Bloomington, Indianapolis: Indianapolis University Press.

More, M. S. 2005. Sartre and the problem of racism. Unpublished doctoral dissertation in Philosophy. Pretoria: UNISA.

More, M. S. 2006. "Philosophy in South Africa under and after apartheid." In:A companion to African Philosophy, edited by K. Wiredu, 149-160. Malden, Oxford: Blackwell.

Okeja, U. 2012. "Space contestations and the teaching of African Philosophy in African Universities." South African Journal of Philosophy 31 (4): 664-75. doi:10.1080/02580136.201 2.10751800 .

Oruka, H. O. 1987. "African Philosophy: A brief personal history and current debate." In: Contemporary Philosophy. A new survey. Volume 5: African Philosophy, edited by G. Fløstad, 45-77. Dortrecht, Dortmundt, Lancaster: Marthinus Nijhof. doi:10.1007/978-94-009-3517-4_3.

Ramphele, M. 1991. "The dynamics of gender within Black Consciousness organisations: A personal view." In: Bounds of possibility: The legacy of Steve Biko and Black Consciousness, edited by N. B. Pityana, M. Ramphele, M. Mpumlwana, and L. Wilson, 214-227. Cape Town: David Philip.

Shutte, A. 1993. Philosophy for Africa. Cape Town: UCT Press.

Serequeberhan, T., ed. 1991. African Philosophy: the essential readings. New York: Paragon House.

Serequeberhan, T. 1994. The hermeneutics of African philosophy. Horizon and discourse. New York: Routledge.

Sesanti, S. 2015. "Teaching African Philosophy in African institutions of higher learning: The implications for African renaissance." South African Journal of Philosophy 34 (3): 346-57. doi:10.1080/02580136.2015.1072451.

Snyman, J. J. 1985. Theodor W. Adorno: Kritiek en utopie. Unpublished doctoral dissertation in Philosophy, RAU [now University of Johannesburg], Johannesburg.

Taiwò, O. 2010. How colonialism pre-empted modernity in Africa. Bloomington: Indiana University Press.

Troup, F. 1975. South Africa: an historical introduction. Harmondsworth: Penguin.

Tshiamalenga, N. 1979. "Die Philosophie in der aktuellen Situation Afrikas." Zeitschrift für Philosophische Forschung 33 (3): 428-33.

Turner, R. 1971. "The relevance of contemporary radical thought." In: Directions of change in South African politics, edited by P. Randall, 73-85. Johannesburg: SPRO-CAS.

Versfeld, M. (1948) 2010. Oor gode en afgode. Pretoria: Protea.

Versfeld, M. 1979. Our selves. Cape Town: David Philip.

Visagie, J. H. N. (n.d.). "Wêreldbeskouings en ideologieë. Study guide for FIL 210. Department of Philosophy." University of Pretoria.

wa Thiong'o, N. 1986. Decolonising the mind. The politics of language in African literature. London \& Nairobi: James Currey \& Heinemann.

Wiredu, K. 1998. "Toward decolonizing African philosophy and religion." African Studies Quarterly 1 (4): 17-46.

Wolff, E. 2010. "Selfkennis en verstandigheid in "n tyd van politieke raserny" [Self-knowledge and prudence in an era of political insanity], Preface in: Oor gode en afgode, M. Versfeld, 7-40. Pretoria: Protea.

Wolff, E. 2013. "Reform and crises. Notes and questions on the condition of the Human and Social Sciences in South Africa and beyond." Theoria 60 (135): 62-82. doi:10.3167/th.2013.6013504.

Wolff, R. P. 1986-87. "Philosophy in South Africa." Philosophical Forum 18 (2-3): 94-104. 